\title{
A Critical Evaluation of the Twelfth Grade English Language Textbook for Afghanistan High Schools
}

\author{
Mohammad Naim Rahim ${ }^{1}$, Tawos Mohammadi ${ }^{2}, \&$ Aminuddin Hashemi ${ }^{3}$ \\ ${ }^{1}$ Kunduz University, Kunduz 3501, Afghanistan \\ ${ }^{2}$ Shaheed Prof. Rabbani Education University, Kabul, Afghanistan \\ ${ }^{3}$ Takhar University, Takhar, Afghanistan \\ mnaim.rahim@gmail.com
}

\begin{abstract}
ARTICLE HISTORY
Received : 6 March 2021

Revised : : 8 March 2021

Accepted : 4 May 2021
\end{abstract}

\section{KEYWORDS}

English as a Foreign Language

English Textbook

Textbook Evaluation

Textbook Development

Content Analysis

\begin{abstract}
Since textbook evaluation is a prominent task for educational development, hence, the study is motivated to extend the ideas towards the best of English as a foreign language teaching in high schools. Globally, the English language is taught aligned with $21^{\text {st }}$ century skills, yet textbooks are lacking some of these skills and approaches in Afghanistan. Therefore, the study applied a mixed-method to critically evaluate the $12^{\text {th }}$ grade English language textbook of high schools in Afghanistan. The data is collected using an adopted textbook evaluation checklist and a Likert-Scale ranging from "Poor" to "Excellent". Content analysis is used to interpret and describe the meaning qualitatively from the number scale of the item in the checklist. Likert-Scale is also analyzed separately through SPSS. The results show that the aims of the course did not correspond closely to the aims of the teaching program and the needs of the learners in the textbook. However, the layout of the textbook is clear, and the students can find their way if an individual study is intended. In terms of the skills, the textbook stated that it covers all four skills of language learning, but the evaluation indicates a considerable focus on reading, grammar, and vocabulary. In conclusion, the study highlighted that the textbook requires to be updated to be focusing more on topic contents related to the needed skills and to make it more userfriendly. This contributes to promoting textbook development in the Ministry of Education and provides an in-depth understanding of the current status of the available textbooks in the high schools of Afghanistan.
\end{abstract}

\section{Introduction}

The teaching-learning process is based on essential elements such as teacher, student, learning environment, and instructional materials such as handouts, workbooks, teachers' guidebooks, CDs, internet, and textbooks (Khoo \& Knight, 2015). Instructional materials, especially the textbook, as an essential element in the teaching-learning process (Richards, 2001), have been in the midst of discussion for a long time. McGrath (2002) stated that there is desirability of basing the teaching-learning process on textbooks. Cunningsworth (1995) explained that a textbook is essential as a source of activities for learners' practice and communicative interaction, but others such as Hutchinson and Torres (1994) stated that textbook hinders the initiative of the teachers. However, Richards (2001) reported that instructional materials such as textbooks, along with their workbooks and teachers' guide, are the most typical form of instructional materials in teaching language. Considering the importance of textbooks in the language teaching process, it is crucial to choose a textbook that can meet the needs of both teachers and students. Also, it should be appropriate to the level and age of the learners.
Therefore, it is important to find an appropriate textbook for students or understand whether a textbook is suitable to the level and age of the students as well as consider if the textbook meets the needs of the students globally. To address these needs, the study is aimed to critically evaluate the $12^{\text {th }}$ grade English language textbook of high schools in Afghanistan. According to Hutchinson \& Waters (1987), evaluation is the process of judging the fitness of something for a particular purpose. It is done to bring positive changes and satisfactory improvements in a process or an object (Sarem et al., 2013).

Textbook evaluation is also divided into three types: preuse, in-use, and post-use. It means that instructional materials cannot only be evaluated before their use but they could be evaluated while the textbook is in-use and even after the use of the textbooks (McGrath, 2002). According to Sheldon (1988), a textbook is evaluated for two essential purposes. First, it helps the teachers and program developers to choose an appropriate textbook for teaching-learning purposes. Second, it familiarizes the teacher with the strength and weaknesses of the textbook (Mukundan et al. 2011). Hence, the researchers have intended to do an in-use critical evaluation of the 12th-grade English language textbook of high schools in Afghanistan. Since the 
educational systems have remained traditionally due to the civil wars in the country during few decades and the need for transforming schools and universities aligned with the international requirements.

The 12th-grade high school textbook which has been selected for evaluation in this study is published by the Ministry of Education of the Islamic Republic of Afghanistan in 2017. This textbook is currently taught in the 12th-grade of high schools in Afghanistan. The critical evaluation of this textbook is essential because it is used at the national level, and the positive and negative aspects of the textbook affect a vast majority of students learning English as a foreign language. Besides, the researchers, as teachers of the English language, faced problems in the vocabulary used in the $12^{\text {th }}$-grade English language textbook of the high schools. In the meantime, the authors have claimed that in developing this textbook, the level, age, needs, interest of the learners, new methods, and a few $21^{\text {st }}$ century skills such as communication, creativity, and critical thinking have been taken into consideration. Therefore, the critical evaluation of the $12^{\text {th }}$-grade English language textbook of the high schools will not only add to the existing literature in the field of textbook evaluation in Afghanistan, help the EFL students to learn the English language based on the global alignments using $21^{\text {st }}$ century learning approaches, but also facilitates the teachers, the syllabus designers, the textbook developers, and ultimately the Ministry of Education to improve future editions of the textbooks and place more emphasis on the $21^{\text {st }}$ century skills and international requirements. Since Afghanistan as an undeveloped country needs to move towards a developing country and this process can be accelerated through educational development.

\section{Literature Review}

The textbook is considered a vital source of the school curriculum in the education system of any country around the globe; especially, in developing countries where the textbook is viewed as the major source of teaching material for novice teachers (Mahmood, 2010). The textbook is regarded as a guide to be followed by teachers and students in practicing authentic materials in school. Textbooks as teaching materials cannot be neglected in a teaching-learning process. It is also believed that instructional materials, such as textbooks, can be biased and inflexible (Mohammadi \& Abdi, 2014). Katawazai et al. (2019) believed that sometimes curriculum designers and material developers ignore some features of the language structures, and they only rely on one aspect in a textbook. Hence, the more demand for using a textbook in the school curriculum, it can lead the researcher to work more on textbook development and textbook evaluation. Textbook evaluation is not a new concept. When a textbook is developed, there is a need for its evaluation, whether it meets the requirement of the students or not (Mohammadi \& Abdi, 2014).

\subsection{The Importance of Textbook Evaluation}

Concerning the importance of textbook evaluation, one can find many ways of evaluation and criteria to be followed in evaluation (Momand et al., 2019). According to this study, textbook evaluation not only relies on some checklists or a set of criteria. Instead, it is a list of factors in a checklist that can lead to systematic evaluation. The study also stated that evaluating textbooks has a significant impact on the teaching-learning process. According to Igbaria (2013), textbook evaluation can open a new window for teachers and curriculum designers to contribute some useful understanding to the educational system. Therefore, many scholars have focused their attention on textbook evaluation, mostly on ELT textbooks. Ghorbani (2011), evaluated an EFL textbook on Quantification and Graphic Representation. The finding of this evaluation shows that $63 \%$ of the evaluated textbook rejects the universal criteria. The findings also suggested the curriculum designers and curriculum developers restructure their materials that can meet the needs of the students.

In addition, Nahrkhalaji (2012), evaluated a universal ELT textbook to examine the relevance of the textbook with the context being used. The findings of evaluation revealed that the majority of the respondents believed that all the aspects of the textbook were relevant to the context, and the needs of the students were met. In the same vein, Tok (2010), focused on the evaluation of the ELT textbook to identify the benefits and challenges of the textbook. The result of the investigation revealed that the textbook could not respond to the needs of the students and the activities were reported irrelevant from the actual needs of the students. Additionally, Rahimpour \& Hashemi (2011), evaluated EFL textbooks to identify the perceptions of teachers in teaching these textbooks. The result of the study revealed that most of the teachers were concerned about the physical make-up and the practicality of the textbook in adopting to EFL teaching context. Therefore, all the studies mentioned above show the importance of textbook evaluation in the English language context.

\subsection{Models for Textbook Evaluation}

Different characteristics of textbooks, such as validity, authenticity, credibility, and practicality can be measured in evaluating ELT textbooks (Nahrkhalaji, 2012). Basically, various approaches along with different checklists can be used to evaluate ELT textbooks. The majority of evaluation models consist of a thorough analysis of the linguistic context, methodology, research design, skills, aims, and teacher's book. Candlin \& Murphy (1987), presented a model that is mostly viewed as a sophisticated approach in critical evaluation of the textbook aims and authenticity. One year after, Sheldon (1988), offered a checklist containing various factors related to content fluctuating from graphics to flexibility. McDonough \& Shaw (2012), provided frameworks consist of a brief external impression for textbook adoption, followed by a short internal evaluation framework for textbook adaptation. Chali \& Conard (1991), 
presented Bloom's Taxonomy of the Cognitive Domain as the affective and cognitive skills assessed through the Question Complexity Rating Scale. Another model proposed by Windeatt (1989), is considered as the initial way to evaluate materials within the broader context focusing on cognitive skills, required knowledge, and attitudes.

\subsection{Previous Studies}

Many studies have been conducted in EFL and ESL contexts to evaluate the suitability of the textbooks for a particular purpose, but textbook evaluation studies are almost none in Afghanistan. Only a study conducted by Katawazai et al. (2019), evaluated the sub-skills (vocabulary, grammar, and pronunciation) in the $9^{\text {th }}$-grade English language textbook for secondary schools in Afghanistan. The results of this study indicated that the textbook lacked contextualized use of the vocabulary, systematic representation and sufficient explanation of grammatical points, and the appropriate representation of pronunciation activities. The study also stated that the textbook needs improvement in terms of grammar and pronunciation.

Another study conducted by Tani (2014), compared the two versions of the mathematics textbooks of grade 9 and 7 of schools: the old version and the new version. Besides, the perception of teachers about two different versions of the textbooks were also collected. The result of the study indicated that the new textbooks were designed better than old textbooks. The new textbook included charts, graphs, and diagrams. However, it is considered difficult to be taught, and not appropriate to the level of the students. Therefore, the reviews of the previous literature in the field of textbooks analysis in Afghanistan indicates that the textbooks produced for the schools need improvement so that they fit the level and age of the students, and also contribute to the acquisition of the English language through the $21^{\text {st }}$ century skills.

\section{Method}

The study applied a mixed-method using an adopted textbook evaluation checklist and a Likert-Scale. A selfreporting technique is performed. All the evaluators are Master of Education in (TESL) at Universiti Teknologi Malaysia (UTM). Besides, the evaluators are English language and literature lecturers in three different universities in Afghanistan. They aimed to do an in-use critical evaluation of the $12^{\text {th }}$-grade English language textbook in order to enlist future suggestions to develop the textbook in hand. The textbook is published by the Ministry of Education of the Islamic Republic of Afghanistan in 2017. It has 12 units with a total of 166 pages. Each unit strongly focuses on reading, vocabulary, and grammar; the other skills, such as listening and writing, have not been given enough attention. The book is currently taught in the $12^{\text {th }}$ grade of high schools in Afghanistan.

The textbook is evaluated based on the Cunningsworth (1995) checklist and a Liker-Scale. Mixed-method is selected because the researchers collect both quantitative and qualitative data. A mixed-method design is a method in which a mixture of qualitative and quantitative data is collected and analyzed in a single study in order to gain a more insightful understanding of the problem (Creswell \& Clark, 2017). Also, Creswell (2012) clarified that mixedmethod design is used when single research, either qualitative or quantitative, is not enough to tackle the problem. Therefore, mixed-method provides sufficient data to address the issue in this particular study.

The quantitative data is collected using (Cunningsworth, 1995) checklist. This checklist of textbook evaluation contains eight sections, namely aim, and approaches, which include four statements. The design and organization section includes six statements. The language content section includes five statements. The skills section includes six statements. The topic section includes seven statements. The methodology section includes eight statements. The teachers' books section includes five statements, and last but not least, the practical consideration section includes four items. The overall items included in the eight sections are 45.

A Likert-Scale ranging from "Poor" to "Excellent" is added to the checklist for deeper understanding, where the researchers read each item and according to their own beliefs, and choose a number between 1 to 4 . The researchers are aware that the 1-4 scores signify the following measures: Poor (1) Fair (2) Good (3) Excellent (4). Content analysis is used to interpret and describe the meaning qualitatively from the number scale of the item in the checklist. As discussed earlier, the eight parts of the checklist are analyzed separately through SPSS. The descriptive statistics Mean and Standard Deviation are presented in the tables, and in order to provide a clear picture of the analysis, the data is illustrated qualitatively.

\section{Results \& Discussions}

The English language textbook for Afghanistan high schools is evaluated by the researchers themselves. The results of the quantitative data indicate that the textbook of $12^{\text {th }}$ grade for Afghanistan high schools needs significant improvements in almost all of the sections evaluated in this study. In the checklist, there were eight sections, from the total, there are five sections that are rated poor by the evaluators: Design and Organization, Language Content, Skills, Methodology, and Teacher's Book. Three sections of the textbook which are rated fair by the evaluators: Aims and Approaches, Topics, and Practical Considerations. In addition to the use of the checklist as an evaluation tool for the $12^{\text {th }}$-grade textbook, the researchers discussed each item of the checklist about the textbook between themselves. The results of the researchers' discussion and the checklist are discussed in detail below.

\subsection{Aims and Approaches}

Table 1 indicates that the items in this section of the checklist are rated as fair with an overall mean of $(\mathrm{M}=2.3)$ by the evaluators. 
Table 1. The Statements in Aims and Approaches Section of the Checklist, the Individual Mean and Standard Deviation, and the Overall Mean

\begin{tabular}{|c|c|c|c|}
\hline \multirow{2}{*}{ No. } & \multicolumn{3}{|c|}{ Aims \& Approaches } \\
\hline & Statements & \multirow{2}{*}{$\begin{array}{l}\text { Mean } \\
2.4\end{array}$} & \multirow{2}{*}{$\frac{\text { Std. D }}{0.89}$} \\
\hline 1 & $\begin{array}{l}\text { Do the aims of the course-book } \\
\text { correspond closely with the aims of } \\
\text { the teaching program and with the } \\
\text { needs of the learner? }\end{array}$ & & \\
\hline 2 & $\begin{array}{l}\text { Is the course-book suited to the } \\
\text { learning/teaching situation? }\end{array}$ & 2.6 & 0.54 \\
\hline 3 & $\begin{array}{l}\text { How comprehensive is the course- } \\
\text { book? Does it cover most of all of } \\
\text { what is needed? Is it a good resource } \\
\text { for students and teachers? }\end{array}$ & 2.2 & 0.44 \\
\hline 4 & $\begin{array}{l}\text { Is the course-book flexible? Does it } \\
\text { allow different teaching and learning }\end{array}$ & 2.0 & 1.00 \\
\hline \multicolumn{2}{|c|}{ Overall Mean } & \multicolumn{2}{|c|}{$2.3=$ Fair } \\
\hline
\end{tabular}

This section is rated fair because the aims of the course did not correspond closely to the aims of the teaching program and the needs of the learners. At the beginning of the textbook, it has been mentioned that the textbook should promote the power of thinking in students, creativity, search and research skills, and communication ability, but in the textbook, most of the activities are fill in blanks, short answers, underlining, and True and False type of activities which according to the researchers do not support the general objectives of the textbook as Rahmawati (2018) stated that the objectives of the teaching-learning program determine the materials and the type of activities/exercises. The study added that the content of the textbook should correspond to the learners' needs in terms of language skills, items, and communicative strategies. Although there are a few activities such as discussion questions at the beginning of each unit or comprehension questions after each reading passage which may help to promote the thinking and communication skills of the students, it is not enough because information and activities are the two elements in a textbook which lead the learner toward the objective (Khoo \& Knight, 2015). Generally, the textbook does not meet all the needs of the learners. There is too little variety in the activities, but still, it is suitable for the teaching-learning situation in Afghanistan.

\subsection{Design and Organization}

The usual pattern of the textbook is that each unit starts with the topic and the aims for the unit. At the beginning of each unit, usually, there are discussion questions regarding the main topic of the unit followed by conversation activity, then grammatical points with exercise either new or revision of the grammar from the previous units. After the grammar, the reading passage is presented with some activities, the vocabulary list, along with exercise, and a new or revision of the previous grammar is presented in the sequence.
Table 2. Design and Organization of the Textbook

\begin{tabular}{|c|c|c|c|}
\hline \multirow{2}{*}{ No. } & \multicolumn{3}{|c|}{ Design and Organization } \\
\hline & Statements & Mean & Std. D \\
\hline 1 & $\begin{array}{l}\text { What components make up the } \\
\text { total course package (e.g., } \\
\text { students' books, teacher's books, } \\
\text { workbooks, cassettes)? }\end{array}$ & 2.2 & 0.84 \\
\hline 2 & $\begin{array}{l}\text { How is the content organized } \\
\text { (e.g., according to structures, } \\
\text { functions, topics, skills, etc.)? }\end{array}$ & 1.6 & 0.55 \\
\hline 3 & $\begin{array}{l}\text { How is the content sequenced } \\
\text { (e.g., on the basis of complexity, } \\
\text { "learn-ability," usefulness, etc.)? }\end{array}$ & 1.6 & 0.55 \\
\hline 4 & $\begin{array}{l}\text { Are the grading and progression } \\
\text { suitable for the learners? Does it } \\
\text { allow them to complete the work } \\
\text { needed to meet any external } \\
\text { syllabus requirements? }\end{array}$ & 1.2 & 0.45 \\
\hline 5 & $\begin{array}{l}\text { Are the reference sections for } \\
\text { grammar, etc.? Are some of the } \\
\text { materials suitable for individual } \\
\text { study? }\end{array}$ & 2.8 & 0.84 \\
\hline 6 & $\begin{array}{l}\text { Is it easy to find your way around } \\
\text { the course-book? Is the layout } \\
\text { clear? }\end{array}$ & 2.0 & 0.71 \\
\hline Over & Mean & $1.9=$ & or \\
\hline
\end{tabular}

The researchers rated this part of the textbook as poor with a mean score of $(M=1.9)$. The evaluation of the textbook revealed that it lacks some essential components such as listening cassettes and workbooks, but it does have a teacher's book. In the textbook, at the beginning of each unit, the summary of the content of that unit is not provided. The textbook also does not have answer keys at the end of the textbook so that the students can evaluate their performance after each activity.

The contents in the textbook are organized according to the topics. The researchers believe that the topics do not have immediate daily use and have been selected haphazardly. Also, the organization and sequencing of the content in the textbook are poor because, in addition to the lack of a logical and functional link between units, the content is not graded in order of difficulty. In the meantime, all four skills of the language are not presented in-balance in the textbook. The distribution of language skills in all units is not equal. All the units have reading, grammar, vocabulary and to some extent, speaking skills, but only two units have Listening and Writing skills. Besides, the grading and progression of the grammatical points are neither systematic nor in order of difficulty. For example, in the first unit of the textbook, Yes/No questions and WH questions are explained, but in the second unit, the passive form of the Past Perfect Tense is 
presented. It shows that the grading and progression of the content, such as grammar and main topics of the units, are haphazardly organized, not based on simple to complex formulas. However, the layout of the textbook is clear, and the students can find their way in the textbook if an individual study is intended.

\subsection{Language Content}

The language and content section of the checklist had five items. The textbook is categorized as poor in terms of content with a mean score of $(\mathrm{M}=1.84)$.

Table 3. Language Content of the Textbook

\begin{tabular}{|c|c|c|c|}
\hline \multirow{2}{*}{ No. } & \multicolumn{3}{|c|}{ Language Content } \\
\hline & Statements & Mean & Std. D \\
\hline 1 & $\begin{array}{l}\text { Does the course-book cover the } \\
\text { main grammar items appropriate } \\
\text { to each level, taking learners' } \\
\text { needs into account? }\end{array}$ & 3.2 & 0.84 \\
\hline 2 & $\begin{array}{l}\text { Is material for vocabulary } \\
\text { teaching adequate in terms of } \\
\text { quantity and range of vocabulary, } \\
\text { the emphasis placed on } \\
\text { vocabulary development, } \\
\text { strategies for individual learning? }\end{array}$ & 2.2 & 0.45 \\
\hline 3 & $\begin{array}{l}\text { Does the course-book include } \\
\text { material for pronunciation work? } \\
\text { If so, what is covered: individual } \\
\text { sounds, word stress, sentence } \\
\text { stress, intonation? }\end{array}$ & 1.2 & 0.45 \\
\hline 4 & $\begin{array}{l}\text { Does the course-book deal with } \\
\text { the structuring and conventions } \\
\text { of language use above sentence } \\
\text { level, for example, how to take } \\
\text { part in conversations, how to } \\
\text { structure a piece of extended } \\
\text { writing, how to identify the main } \\
\text { points in a reading passage? } \\
\text { (More relevant at intermediate } \\
\text { and advanced levels). }\end{array}$ & 1.2 & 0.45 \\
\hline 5 & $\begin{array}{l}\text { Are style and appropriacy dealt } \\
\text { with? If so, is language style } \\
\text { matched so social situation? }\end{array}$ & 1.4 & 0.55 \\
\hline Ove & all Mean & $1.84=$ & oor \\
\hline
\end{tabular}

The quantitative analysis of this section indicated that the language contents are poor in the textbook since the grammatical points are not appropriate to the level and needs of the students. As an example mentioned in the previous section, the first unit presents Yes/No and WH questions while the second unit presents the passive form of the Past Perfect Tense. There is a significant gap between these two grammatical points shown.

Moreover, McDonough \& Shaw (2012) stated that understanding vocabulary is considered an integral part of a learner's overall competency in a foreign language. The vocabulary in a textbook should be functional for the students; it means that the vocabulary should have practical daily use. However, in terms of the number of vocabulary items, there is a proper distribution of the vocabulary in each unit. On average, 17 new words are presented in the list in each unit. Based on the vocabulary list in each unit, a total number of 200 new words are presented in the textbook. However, not enough stress is placed on the vocabulary learning strategies, and not enough exercises have been created for internalizing vocabularies. For instance, in each unit, there is only one, rarely two vocabulary exercises. Most of these exercises are fill in the blanks or matching, which are not enough for learning the vocabularies. However, in the teacher's guidebook, it is claimed that the process of recalling and recycling the words occurs continuously in the textbook, but since there is no link between the topics of the units, there is a limited opportunity that the words get repeated in the subsequent units to reinforce the meaning and use. Raval (2013) stated that in order to consolidate the use of new words, they should be repeated in the text. In terms of lack of exercise for recycling the new words, the results of this evaluation are in line with that of Katawazai et al. (2019).

Celce-Murcia et al. (2010) stated that pronunciation is a salient feature of English language competency, and it is essentially more than any other aspect of the English language. In the textbook, the pronunciation of the vocabularies is not given attention at all. There is no pronunciation of the vocabulary items, word stress, sentence stress, or intonation exercise available in the textbook. Therefore, it is better to add pronunciation, word stress, and intonation so that the students understand naturally spoken English. The result of this study in terms of the pronunciation is consistent with that of Katawazai et al. (2019), in which he also stated that the grade 9 textbook lacks a suitable representation of the pronunciation.

A strong point in the grammar section of the textbook is that the grammatical points from the earlier units are repeated in a revision section in the upcoming units. Also, grammar is presented with extensive practice, but the negative point about the grammar in the textbook is that it is not organized in order of difficulty. For example, in the second unit, the passive form of the Past Perfect Tense has been explained, but in unit three, the Past Continuous Tense is explained. It means that grammar is not presented systematically and in a clear line of progression to suit the growing proficiency level of the students. Also, the activities which require the students to practice the grammatical point do not reflect real-life situations. In terms of the presentation of grammar in a systematic way and based on the simple to a complex formula, the current study contends the results of Katawazai et al. (2019) study. It also contends the mentioned study in terms of the recycling of the grammar in the upcoming units. The current study found out that the grammatical points are revised and recycled in the upcoming units. 


\subsection{Skills}

The skills section which had six statements was rated as fair with a mean score of $(M=1.7)$. In the teacher's book, it has been mentioned that the textbook covers four main skills of the English language, namely, Reading, Writing, Speaking, and Listening, but when the researchers evaluated the textbook, a considerable focus was placed on reading, grammar, and vocabulary.

Table 4. Skills of the Textbook

\begin{tabular}{|c|c|c|c|}
\hline \multirow[b]{2}{*}{ No. } & \multicolumn{3}{|l|}{ Skills } \\
\hline & Statements & Mean & $\begin{array}{l}\text { Std. } \\
\text { D }\end{array}$ \\
\hline 1 & $\begin{array}{l}\text { Are all four skills adequately } \\
\text { covered, bearing in mind your } \\
\text { course aims and syllabus } \\
\text { requirements? }\end{array}$ & 1.6 & 0.55 \\
\hline 2 & $\begin{array}{l}\text { Is there material for integrated } \\
\text { skill work? }\end{array}$ & 1.2 & 0.45 \\
\hline 3 & $\begin{array}{l}\text { Are reading passages and } \\
\text { associated activities suitable } \\
\text { for your students' level, } \\
\text { interests, etc.? Is there } \\
\text { sufficient reading material? }\end{array}$ & 2.8 & 0.84 \\
\hline 4 & $\begin{array}{l}\text { Is listening material well } \\
\text { recorded, as authentic as } \\
\text { possible, accompanied by } \\
\text { background information, } \\
\text { questions, and activities that } \\
\text { help comprehension? }\end{array}$ & 1.4 & 0.54 \\
\hline 5 & $\begin{array}{l}\text { Is material for spoken English } \\
\text { (dialogues, role plays, etc.) } \\
\text { well designed to equip } \\
\text { learners for real-life } \\
\text { interactions? }\end{array}$ & 1.6 & 0.54 \\
\hline 6 & $\begin{array}{l}\text { Are writing activities suitable } \\
\text { in terms of the amount of } \\
\text { guidance/control, degree of } \\
\text { accuracy, organization of } \\
\text { longer pieces of writing (e.g., } \\
\text { paragraphing) and use of } \\
\text { appropriate styles? }\end{array}$ & 1.6 & 0.54 \\
\hline
\end{tabular}

\section{Overall Mean}

$1.7=$ Poor

McDonough \& Shaw (2012) stated that reading is one of the most important skills. In the meantime, it is a complex process. From the language acquisition point of view, it is a significant source of language input, especially in countries like Afghanistan, where English is spoken as a foreign language (Rahim \& Sandaran, 2021). The reading section of the $12^{\text {th }}$-grade English language textbook is topic-based.
Each unit has a specially written passage about the main topic of the unit, which focuses on vocabulary and grammar points. McDonough \& Shaw (2012) stated that such an arrangement of the unit where it starts with a reading passage to present particular vocabulary and grammar is a traditional way of organizing materials. In the reading section of the textbook, there is no variety of styles and texts, while the students need to get exposed to different types of reading materials to get familiar with the variety of styles and texts. The readings in the textbook consider the learner as an empty vessel to be filled, while the students do not need information, but they need to develop their reading ability. The researchers suggest that the reading text should be of students' interest and challengeable. It should engage the learner in the text and should be relevant to them. Also, it should encourage dialogue with the writer by expecting the students to anticipate what will happen next in the text. It should also introduce different reading strategies. The activities after reading are too simple, such as comprehension questions and fill in the blanks. It could be replaced with communicative activities such as the information gap, which is also an activity of integrated skills of reading, listening and speaking, text scrambling, and reaction to the text. The reading passages are too long, and it has new words more than the amount provided in the vocabulary list provided after the reading. The text could be divided into many small pieces and taught in different sections of the unit.

Besides, the researchers found only two listening activities at the beginning of units five and seven. These two listening activities are inauthentic, unrecorded, and no authentic pronunciation and activities are included for the learners to practice listening skills. In the only two listening activities, the teacher is expected to talk about a specific topic, and the students have to listen. Such listening activities do not improve the listening skill of the learners as long as the listening activities are not authentic. McDonough \& Shaw (2012) stated that listening should be for a purpose; for example, the writers of the textbook could add authentic activities that could engage the learners in active learning. Listening activities should engage the learners in active learning; for example, sequencing the picture in the right order, following a direction on a map, checking items in a picture, or completing a chart; such activities are not only suitable to the level of $12^{\text {th }}$-grade students, but can promote the listening skill of the learners as well.

Speaking is the ability to communicate something to achieve an end (McDonough \& Shaw, 2012). The primary function of language is for interaction and communication (Richards, 2001). The speaking skill is not only crucial for the oral expression of ideas, but it also reinforces the use of vocabulary, pronunciation, and structure of the language. Therefore, it should be given enough attention for teaching the English language. In the textbook, the conversation activities are limited to a dialogue between two people; such activities are named pre-communicative language teaching activities. 
It could be effective for the students at a low level, but for the $12^{\text {th }}$-grade level, more complicated speaking activities such as information gap, describing, asking for feedback, and guessing unknown information are expected. It engages the learner in real communication. Although the existing activities are short, they still help the learners to communicate.

In the textbook, there is no separate section for writing, but it is merged with other sections. The very traditional writing activities, such as Controlled Sentence Construction have been used. The students are provided a model sentence, and then they are asked to provide a parallel sentence with different lexical items. Another activity is that the students have to insert missing grammatical forms in the sentence. Generally speaking, the writing in the $12^{\text {th }}$-grade textbook is limited to the sentence level.

By considering the proficiency level of the students, it is expected that the writing at this level should be beyond sentence level, at least in paragraphs. According to the researchers, suitable writing activities for the students at this level could be building a piece of writing from the answers, selecting appropriate connectives for a piece of writing, (re)constructing paragraph from jumbled sentences or a whole text from jumbled paragraphs, paragraph or story completion tasks, choosing an appropriate title for a paragraph or a whole text (McDonough \& Shaw, 2012). These activities should lead to more complicated writing by the end of the textbook, such as process writing, in order to prepare the students for writing at the university level.

Richards \& Schmidt (2013) define an integrated approach as the teaching of language skills in conjunction with each other. The lessons in an integrated teaching approach include the activities that relate Listening and Speaking to Reading and Writing. In the textbook, the integrated approach has been given very little attention. Most of the activities are designed for practicing only one skill at a time. Rahim (2021) also stated that the dominant skills of the classic curriculum of teaching and testing are reading skills, memorization skills, repetition drills, and corrections which is aligned with Education 1.0. Therefore, for designing textbooks aligned with Education 5.0, it is necessary to consider the integration of $21^{\text {st }}$ century skills (Rahim, 2021).

\subsection{Topics}

The Topic section of the checklist has seven items for the evaluation of the topics in the textbook. The topics in the textbook are evaluated as fair, with a mean score of $(\mathrm{M}=$ 2.37).
Table 5. Topics of the Textbook

\begin{tabular}{|c|c|c|c|}
\hline \multirow{2}{*}{ No. } & \multicolumn{3}{|l|}{ Topics } \\
\hline & Statements & Mean & Std. D \\
\hline 1 & $\begin{array}{l}\text { Is there sufficient material of } \\
\text { genuine interest to learners? }\end{array}$ & 1.8 & 1.3 \\
\hline 2 & $\begin{array}{l}\text { Is there enough variety and } \\
\text { range of topics? }\end{array}$ & 3.0 & 0.71 \\
\hline 3 & $\begin{array}{l}\text { Will the topics help expand } \\
\text { students' awareness and enrich } \\
\text { their experience? }\end{array}$ & 3.0 & 1.00 \\
\hline 4 & $\begin{array}{l}\text { Are the topics sophisticated } \\
\text { enough in content, yet within } \\
\text { the learners' language level? }\end{array}$ & 3.2 & 0.45 \\
\hline 5 & $\begin{array}{l}\text { Will your students be able to } \\
\text { relate to the social and cultural } \\
\text { contexts presented in the course- } \\
\text { book? }\end{array}$ & 2.8 & 0.84 \\
\hline 6 & $\begin{array}{l}\text { Are women portrayed and } \\
\text { represented equally with men? }\end{array}$ & 1.0 & 0.00 \\
\hline 7 & $\begin{array}{l}\text { Are other groups represented, } \\
\text { with reference to ethnic origin, } \\
\text { occupation, disability, etc.? }\end{array}$ & 1.8 & 1.10 \\
\hline
\end{tabular}

Overall Mean

2.37 = Fair

In the textbook, there are 12 units, each unit representing a different topic. The good point about the topics is that the topics are not culturally or religiously sensitive. Yulianti (2011) stated that the materials in the textbook should not be culturally biased. It means that in a textbook, every material should be presented neutral and equal (Rynanta \& Ruslan, 2013). However, most of the topics are not of students' interest because it does not have daily use. Also, the topics are not arranged in a logical sequence. Although the topics are full of new words and are sophisticated enough in content yet within the learner's language level. It does not seem to enrich students' experiences. In addition, throughout the textbook, males and females are not portrayed equally, and other groups such as the disabled are not represented in the textbook.

\subsection{Methodology}

The methodology in the textbook is rated as poor with a mean score of $(\mathrm{M}=1.95)$ by the researchers. 
Table 6. Methodology of the Textbook

\begin{tabular}{|c|c|c|c|}
\hline \multirow{2}{*}{$\begin{array}{c}\text { No } \\
\cdot\end{array}$} & \multicolumn{3}{|l|}{ Methodology } \\
\hline & Statements & $\begin{array}{c}\text { Mea } \\
\mathbf{n}\end{array}$ & $\begin{array}{c}\text { Std. } \\
\text { D }\end{array}$ \\
\hline 1 & $\begin{array}{l}\text { What approach/approaches to } \\
\text { language learning are taken by } \\
\text { the course-book? Is this } \\
\text { appropriate to the } \\
\text { learning/teaching situation? }\end{array}$ & 1.60 & 0.89 \\
\hline 2 & $\begin{array}{l}\text { What level of active learner } \\
\text { involvement can be expected? } \\
\text { Does this match your students' } \\
\text { learning styles and } \\
\text { expectations? }\end{array}$ & 2.00 & 0.00 \\
\hline 3 & $\begin{array}{l}\text { What techniques are used for } \\
\text { presenting/practicing new } \\
\text { language items? }\end{array}$ & 2.80 & 0.45 \\
\hline 4 & $\begin{array}{l}\text { Are they suitable for your } \\
\text { learners? }\end{array}$ & 2.00 & 0.00 \\
\hline 5 & $\begin{array}{l}\text { How are the different skills } \\
\text { taught? }\end{array}$ & 1.80 & 0.45 \\
\hline 6 & $\begin{array}{l}\text { How are communicative } \\
\text { abilities developed? }\end{array}$ & 1.40 & 0.54 \\
\hline 7 & $\begin{array}{l}\text { Does the material include any } \\
\text { advice/help to students on study } \\
\text { skills and learning strategies? }\end{array}$ & 1.40 & 0.55 \\
\hline 8 & $\begin{array}{l}\text { Are students expected to take a } \\
\text { degree of responsibility for their } \\
\text { own learning (e.g., by setting } \\
\text { their own individual learning } \\
\text { targets)? }\end{array}$ & 2.60 & 0.55 \\
\hline Ove & all Mean & $1.95=$ & Poor \\
\hline
\end{tabular}

After scrutinizing the textbook, it is revealed that the textbook widely relies on the GMT (Grammar-Translation Method). According to Rahim (2021), in GMT, language is taught through reading and translation skills and the focus is on memorization. In the textbook, a considerable focus is given to the reading section, and after the reading, there are some activities such as fill in the blanks and comprehension questions from the text. Besides, in the GTM, colossal attention is given to grammar, but little attention is given to the use of language for communication where teaching and learning are not aligned with Education 5.0 (Rahim, 2021). In the textbook, as mentioned earlier, considerable attention is given to grammar. Grammatical points have been explained before and after reading tasks, but for the use of language for communication purposes, there is only one conversation activity at the beginning of the textbook.
Moreover, in the textbook, the grammar is presented deductively, and then there are some exercises to practice the grammatical rules. Zhou \& Niu (2015) stated that in the grammar-translation method, the grammar is presented deductively. The students are expected to memorize the rules and use the rules in examples through activities such as Fillin-the-blanks, use of words in sentences, and synonym/antonym (Larsen-Freeman, 2000).

Even though the learners are involved in the learning process through the activities and tasks in the textbook, the involvement of learners in teaching and learning activity through the use of GMT does not contribute to Education 5.0 and making the students communicatively competent (Rahim, 2021). Because the students are engaged in reading and memorizing the grammatical rules as these two aspects of the English language are given huge attention.

Throughout the textbook, pair-work, individual work, and discussion are the techniques which are used for the practice of new language items. The speaking activity is taught through dialogue and discussion. In most cases, the discussion activities are based on some questions presented at the beginning of the unit, which could be boring for the students. The developers of the textbook could bring a variety of discussion activities such as describing pictures, picture differences, things in common, or solving a problem; such activities could not only improve the speaking of the student, but it could make the teaching-learning process interesting for the students.

The reading is taught through reading passage plus answering comprehension questions, which is a conventional type of reading activity (Ur, 1996). According to Ur (1996), answering the comprehension questions does not mean that the student reads the text successfully at all. The comprehension questions could be a good activity for reading, but if the questions do not need a verbatim answer. In most cases, the comprehension questions are too easy that the students can lift the answer from the text with no real understanding of the text (McDonough \& Shaw, 2012). Instead, the answers to comprehension questions could expect the students to paraphrase, interpret, use background knowledge, and finally engage the learner in the reading. Such questions can have more than one possible answer and motivate discussion (Ur, 1996). The writers of the textbook could add more reading activities such as provide a title, Continue, mistakes in the text, comparison, and representation of the content. To conclude, the activities do not encourage collaboration, group work, and cooperation in the textbook.

\subsection{Teachers' Book}

This section of the textbook is rated as poor with a mean score of $(M=1.96)$ by the researchers. 
Table 7. Teachers' Book

\begin{tabular}{|c|c|c|c|}
\hline \multirow[b]{2}{*}{ No. } & \multicolumn{3}{|c|}{ Teacher's Book } \\
\hline & Statements & Mean & $\begin{array}{c}\text { Std. } \\
\text { D }\end{array}$ \\
\hline 1 & $\begin{array}{l}\text { Is there adequate guidance for the } \\
\text { teachers who will be using the } \\
\text { course-book and its supporting } \\
\text { materials? }\end{array}$ & 1.80 & 1.09 \\
\hline 2 & $\begin{array}{l}\text { Are the teachers' books } \\
\text { comprehensive and supportive? }\end{array}$ & 1.60 & 0.89 \\
\hline 3 & $\begin{array}{l}\text { Do they adequately cover } \\
\text { teaching techniques, language } \\
\text { items such as grammar rules and } \\
\text { culture-specific information? }\end{array}$ & 1.60 & 0.89 \\
\hline 4 & $\begin{array}{l}\text { Do the writers set out and justify } \\
\text { the basic premises and principles } \\
\text { underlying the material? }\end{array}$ & 2.20 & 1.64 \\
\hline 5 & $\begin{array}{l}\text { Are the keys to the exercises } \\
\text { given? }\end{array}$ & 2.60 & 1.52 \\
\hline Over & all Mean & $1.96=$ & oor \\
\hline
\end{tabular}

The positive point is that the textbook has a teacher's book with step-by-step instructions for the teachers, starting from greeting to the keys to the exercises. The teacher's book is comprehensive, and in the meantime, it is supportive for the teachers. It also explains how a particular lesson should be conducted and what teaching and learning techniques should be used. But the negative point in the teacher's book is that it does not encourage communicative activities.

\subsection{Practical Consideration}

In terms of practical considerations, the textbook is rated as fair, with a mean score of $(\mathrm{M}=2.25)$.

Table 4.8 Practical Consideration of the Textbook

\begin{tabular}{|c|c|c|c|}
\hline \multirow[b]{2}{*}{ No. } & \multicolumn{3}{|c|}{ Practical Considerations } \\
\hline & Statements & Mean & $\begin{array}{c}\text { Std. } \\
\text { D }\end{array}$ \\
\hline 1 & $\begin{array}{l}\text { What does the whole package cost? } \\
\text { Does this represent good value for } \\
\text { money? }\end{array}$ & 2.00 & 0.71 \\
\hline 2 & $\begin{array}{l}\text { Are the books strong and long- } \\
\text { lasting? Are they attractive in } \\
\text { appearance? }\end{array}$ & 2.60 & 0.54 \\
\hline 3 & $\begin{array}{l}\text { Are they easy to obtain? Can further } \\
\text { supplies be obtained at short notice? }\end{array}$ & 2.40 & 1.14 \\
\hline 4 & $\begin{array}{l}\text { Do any parts of the package require } \\
\text { particular equipment, such as a } \\
\text { language laboratory, a listening } \\
\text { center, or a video player? If so, do } \\
\text { you have the equipment available } \\
\text { for use and is it reliable? }\end{array}$ & 2.00 & 1.00 \\
\hline
\end{tabular}

Overall Mean

$2.25=$ Fair
It indicates that the book has been in fair physical makeup, and it could be improved. The book is provided free on loan in all public schools to the students and teachers. In case some students need it, it could be found at a very low price in bookstores in Afghanistan. A positive point of the book is that a variety of colors and to a great extent, real pictures are used. The quality of printing is good; the size and the type of text are also appealing. Only some of the main titles of the units are not designed well; in some cases, it needs much focus to read. Illustrations can make the textbook interesting for the students to interact with and motivate them to study (McGrath, 2002). The physical appearance of the textbook is also essential, as stated by Sarem et al. (2013) that students make their first impression of a book by merely looking at the physical appearance of the textbook regardless of the content. The evaluators also believe that the textbook could be designed way better than how it is designed now. In terms of durability, since the textbook is used all over the year by the students, it is expected to be stronger with a hard, waterresistant cover, and with stronger binding so that it does not tear quickly during an academic year. As mentioned earlier, the textbook is provided by the Ministry of Education once a year to the students of the $12^{\text {th }}$ grade of secondary schools.

Moreover, the researcher went through the textbook in order to know if there are errors, mistakes, unclear instruction, or some information that needs to be updated. In the process of examining the textbook, the researchers found some grammatical mistakes which could be due to the carelessness of the writers. Some of the instructions for the activities could be better than the existing ones. Since the textbook was published two years ago, so update information on the topics in the textbook is expected. In some units of the textbook, the information provided is not up to date, such as unit eight which is about the universities in Afghanistan. Also, in the first unit of the textbook, there is the title "Hekmat's Private School," which is not appropriate to be included in the textbook of school, since it would be considered as marketing for the school if any exist with that name.

\section{Conclusion}

The current article disclosed the verdicts based on an inuse critical evaluation of the $12^{\text {th }}$-grade English language textbook of high schools in Afghanistan. While evaluating the textbook, the researchers discovered that the textbook did not cater to the requirements of the students as there are minimal amounts of activity content, but it is still suitable for educational purposes in Afghanistan. In addition, the supply of the four language skills is uneven as the majority of tasks require drillings of one particular skill, and the grammatical points are often used again repetitively in some topic chapters. Based on the best of the researchers, the topics are not sensitive to culture and religion, yet the topics did not seem to attract students' attention due to the lack of practical usage in their daily lives and the tasks did not emphasize much on collaboration, group work, and cooperation. Apart 
from that, there is a diversity of colors, authentic pictures and the printing of fonts, including sizes and types, were appealing. According to the analysis, from eight items evaluated in the textbook, most items in the textbook rated fair. The study recommended revision and updates for the future editions of the textbook by the Ministry of Education and suggested perspective textbook developers in Afghanistan consider the requirements for developing textbooks that are aligned with the students' needs globally.

The study also contributes to the efforts which are vivid that the high schools' textbooks in Afghanistan need to be updated to focus more on context and contents related to the present educational circumstances and to make textbooks more user-friendly. An excellent textbook ought to be able to tally with the curriculum requirements and also attract students' undivided attention to the contents. It should also fulfill the students' needs and address the market demand.

This signifies that the textbook developers integrate more meaningful and up-to-date tasks that utilize all four language skills to enhance the students' language development through the implantation of $21^{\text {st }}$ century skills in teaching and learning. Moreover, the critical evaluation of the $12^{\text {th }}$-grade English language textbook of the high schools in Afghanistan will not only enhance the existing literature in the field of textbook evaluation, but also helps teachers, syllabus designers, textbook developers, and ultimately Ministry of Education to improve accurately the future editions of the textbooks and place more emphasis on the $21^{\text {st }}$ century skills. It also motivates the schools and educational institutions to contribute to the evaluation of teachinglearning materials to align their educational goals with the students' needs and global requirements.

\section{Acknowledgment}

This research is dedicated to the Ministry of Education of Afghanistan for their best in preparing the new generation. Although we express our sincere gratitude to Dr. Shanti S. C. who is one of the leading professors of UTM Malaysia for her guidance and correction during our research project.

\section{References}

Candlin, C. N., \& Murphy, D. (Eds.). (1987). Language learning tasks (Vol. 7). Prentice Hall.

Celce-Murcia, M., Brinton, D. M., \& Goodwin, J. M. (2010). Teaching pronunciation hardback with audio CDs (2): A course book and reference guide: Cambridge University Press.

Chall, J. S., Conard, S. S., \& Harris-Sharples, S. (1991). Should textbooks challenge students? The case for easier or harder textbooks. Teachers College Press.

Creswell, J. W. (2012). Educational research: Planning, conducting, and evaluating quantitative (4th ed.). United States of America: Pearson Publication.
Creswell, J. W., \& Clark, V. L. P. (2017). Designing and conducting mixed methods research: Sage publications.

Cunningsworth, A. (1995). Choosing your coursebook: Heinemann Oxford.

Ghorbani, M. R. (2011). Quantification and graphic representation of EFL textbook evaluation results. Theory and Practice in Language Studies, 1(5), 511520.

Hutchinson, T., \& Torres, E. (1994). The textbook as agent of change. ELT Journal, 48(4) 315-328, https://doi.org/10.1093/elt/48.4.315

Hutchinson, T., \& Waters, A. (1987). ESP: A learning centred approach. Cambridge: $C U P$.

Igbaria, A. K. (2013). A content analysis of the wh-questions in the EFL textbook of "horizons". International Education Studies, 6(7), 200-224.

Katawazai, R., Haidari, M., \& Sandaran, S. C. (2019). An evaluation of sub-skills (vocabulary, grammar and pronunciation) in the grade 9 English textbook of Afghan secondary schools. International Journal of Engineering and Advanced Technology, 8(5), 12361241. https://doi.org/10.35940/ijeat.E1176.0585C19

Khoo, H. S., \& Knight, P. (2015). Teachers' evaluation of KBSM Form 4, 5 English textbooks used in the secondary schools in Penang, Malaysia. Advances in language and literary studies, 6(4), 128-150.

Larsen-Freeman, D. (2000). Techniques and principles in language teaching: Oxford University.

Mahmood, K. (2010). Textbook evaluation in Pakistan: Issue of conformity to the national curriculum guidelines. Bulletin of Education and Research, 32(1).

McDonough, J., \& Shaw, C. (2012). Materials and Methods in ELT: John Wiley \& Sons.

McGrath, I. (2002). Materials evaluation and design for language teaching: Edinburgh University Press.

Mohammadi, M., \& Abdi, H. (2014). Textbook evaluation: A case study. Procedia-Social and Behavioral Sciences, 98, 1148-1155.

Mukundan, J., Hajimohammadi, R., \& Nimehchisalem, V. (2011). Developing an English language textbook evaluation checklist. Contemporary Issues in Education Research, 4(6), 21-28.

Mukundan, J., \& Nimehchisalem, V. (2012). Evaluative criteria of an English language textbook evaluation checklist. Journal of Language Teaching \& Research, 3(6), 1128-1134.

Mushtaq, S. N., Kazimi, F., Zaynal, J., \& Ludin, G. R. (2017). English for Afghanistan: Student's book grade 12. Ministry of Education, Deputy Ministry of 
Curriculum Development \&Teacher Education, Directorate General of Curriculum Development \& Compiling of Textbooks. https://darakhtdanesh.org/en/resource/10254

Nahrkhalaji, S. S. (2012). An evaluation of a global ELT textbook in Iran: A two-phase approach. International Journal of Humanities and Social Science, 2(3), 184191.

Rahim, M. N. (2021). Post-Pandemic of covid-19 and the need for transforming education 5.0 in Afghanistan higher education. Utamax : Journal of Ultimate Research and Trends in Education, 3(1), 29-39. https://doi.org/10.31849/utamax.v3i1.6166

Rahim, M. N., \& Chandran, S. C. (2021). Investigating EFL students' perceptions on e-learning paradigm-shift during covid-19 pandemic. Elsya: Journal of English Language Studies, 3(1), 56-66. https://doi.org/10.31849/elsya.v3i1.5949

Rahimpour, M., \& Hashemi, R. (2011). Textbook Selection and evaluation in EFL context. World Journal of Education, 1(2), 62-68.

Rahmawati, L. (2018). A content analysis of the English textbook" Primary English as a Second Language". [Thesis, UIN Sunan Ampel Surabaya]. Digilib. https://digilib.uinsby.ac.id/23517/

Raval, G. P. (2013). Critical Analysis of English (Second Language) Textbook of Standard VII. Journal of Research in Humanities and Social Sciences, 1(9), 6-9.

Richards, J. C. (2001). Curriculum development in language teaching: Ernst Klett Sprachen.

Richards, J. C., \& Schmidt, R. W. (2013). Longman dictionary of language teaching and applied linguistics: Routledge.

Rynanta, R. A. C., \& Ruslan, S. (2013). Content Analysis on the English Textbook Entitled 'English in Mind Starter (Student's Book)". [Thesis, State Univesity Malang] Repository

UM, http://repository.um.ac.id/id/eprint/245077

Sarem, S. N., Hamidi, H., \& Mahmoudie, R. (2013). A critical look at textbook evaluation: A case study of evaluating an ESP course-book: English for international tourism. International Research Journal of Applied and Basic Sciences, 4(2), 372-380.

Sheldon, L. E. (1988). Evaluating ELT textbooks and materials. ELT journal, 42(4), 237-246. https://doi.org/10.1093/elt/42.4.237

Tani, W. B. (2014). Textbook analysis in Afghanistan: Comparison of mathematics' textbooks of grade 7-9. [Master thesis, Karlstads universitet]. Diva. https://www.divaportal.org/smash/record.jsf?pid=diva2\%3A749499\&d swid $=-8992$
Tok, H. (2010). TEFL textbook evaluation: From teachers' perspectives. Educational Research and Reviews, 5(9), 508.

Ur, P. (1996). A course in language teaching: Practice and theory: Ernst Klett Sprachen.

Windeatt, B. (1989). Classical and Medieval Elements in Chaucer's Troilus. The European Tragedy of Troilus. Oxford http://opac.regesta-imperii.de/id/929641

Yulianti, R. (2011). Content analysis on the English ebook "developing English competencies for senior high school (SMA/MA) grade X”. [Thesis, State University of Malang]. Repository UM, http://repository.um.ac.id/10759/

Zhou, G., \& Niu, X. (2015). Approaches to language teaching and learning. Journal of Language Teaching and Research, 6(4), 798-802. http://dx.doi.org/10.17507/j1tr.0604.11 